\section{TYPOGRAPHICAL ASPECT OF ANIMATED TITLES IN CINEMATOGRAPHY OF THE EARLY DIGITAL ERA}

Oksana Chuieva, https://orcid.org/0000-0002-1877-5010 $\mathrm{PhD}$ in Arts, Associate Professor of the Department of Graphic Design,

Kyiv National University of Culture and Arts,

Kyiv, Ukraine aksanas@gmail.com

Mykhailo Cholii, Master of Design, Kyiv National University of Culture and Arts, Kyiv, Ukraine mixeliusini@gmail.com

\section{ТИПОГРАФІЧНИЙ АСПЕКТ АНІМОВАНИХ ТИТРІВ У КІНЕМАТОГРАФІ ПОЧАТКУ ЦИФРОВОЇ ДОБИ}

\section{Оксана Чуєва,}

https://orcid.org/0000-0002-1877-5010

кандидат мистецтвознавства,

доцент кафедри графічного дизайну, Київський національний університет культури і мистецтв,

Київ, Україна

aksanas@gmail.com

\section{Михайло Чолій,}

магістр дизайну,

Київський національний університет

культури і мистецтв,

Київ, Україна

mixeliusini@gmail.com

\section{Abstract}

The aim of the research is to distinguish the relations between animated titles and the content of feature films. The research methods. Creating animated titles is an applied process, but project preparation requires theoretical analysis of the sources closely connected with the subject of the research, namely: the study of approaches used in the work, and the tools used in design development. The scientific novelty of the research is to find out the main trends in creating animated titles on the basis of isolated samples of feature films of the digital era. Having analyzed the examples, several approaches that successfully combine the tasks set by authors/film scriptwriters have been singled out, such as: font-based solutions based on standard fonts; font accidence that should cause certain associations; combination of fonts and camera work (rotation, panorama, remoteness or approximation of objects, etc.); "gluing" titles into objects; a background where the titles are displayed - a static background or a background "against the background of action"; and titles-cartoons as a special genre Conclusions. The use of fonts in animated titles

\section{Анотація}

Мета дослідження - виявити зв'язок анімованих титрів зі змістом художніх кінофільмів. Методи дослідження. Створення анімованих титрів $є$ прикладним процесом, але проектна підготовка вимагає теоретичного аналізу джерел, дотичних до тематики дослідження, а саме: вивчення підходів, що використовуються у роботі, та інструментарій, задіяний у проектних розробках. Наукова новизна дослідження полягає у виявленні основних напрямків створення анімованих титрів на основі виокремлених зразків художніх фільмів цифрової доби. Аналізуючи приклади, нами було виявлено декілька беззаперечних підходів, які вдало поєднують у собі поставлені авторами / сценаристами кінострічок завдання: шрифтові рішення на базі стандартних шрифтів; шрифтова акциденція, яка має викликати певні асоціації; поєднання шрифтів з роботою камери (обертання, панорама, віддалення або приближення об'єктів тощо); «вклеювання» титрів в об'єкти; тло, на якому експонуються титри - статичне або тло «на тлі дії»; і титри-мультфільми як особли- 
and a separate trend in the animation of titles. from the point of view of their plastic characteristics and compositional possibilities expands the horizons for the further development of each of the trends identified and provides an opportunity for further variation and experimentation. Project activity cannot be limited by rules and set schemes only. The development of technological processes used in practical work leads to a "collision" of fonts with different types of images, which, in its turn, should cause certain programmed emotions from a viewer and adjust the viewer to further watching of a film.

\section{Keywords:}

fonts, animated titles, cinematograph, design, digital era. вий жанр та окремий напрямок розвитку В анімації титрів. Висновки. Використання шрифтів у анімованих титрах з погляду їхніх пластичних характеристик та композиційних можливостей розширює горизонти для подальшого розвитку кожного з визначених напрямків та надає можливість для подальшого варіювання та експериментування. Проектна діяльність не може обмежуватися правилами та усталеними схемами. Розвиток технологічних процесів, що задіяні у практичній роботі, спонукає до «зіткнення» шрифтів з різними видами зображень, що в свою чергу має викликати у глядача певні запрограмовані емоції та налаштовувати на подальший перегляд кінострічки.

Вступ 1 Титри завжди відігравали значну роль у створенні кінострічок. Ще з часів німого кіно вони стали однією з найважливіших частин проекту. Багато в чому саме завдяки письмовим вставкам у вигляді титрів глядачі могли розуміти, що відбувається на екрані. Шрифти в поєднанні з анімацією з погляду пластичних і композиційних можливостей $є$ новим напрямком розвитку сучасного мистецтва. Проектна діяльність не може обмежуватися правилами та існувати в усталених схемах.

\section{Мета 2
дослідження}

Здійснити аналіз типографічного аспекту дизайну анімованих титрів до стрічок цифрової доби, виявити основні напрями дизайну титрів, визначити їх характерні особливості та способи поєднання з візуальним рядом.

Методологія та аналіз джерельної бази
Передбачає виокремлення шрифтової складової в анімованих титрах стрічок цифрової доби, що дозволить перейти до розуміння взаємодії всіх складових елементів, а саме шрифту та зображувального ряду в образному відтворенні авторського / сценарного задуму.

Статус виду мистецтва анімація набула на рубежі XXXXI століть. Саме в цей період були випущені найбільш значущі монографічні наукові роботи практиків анімації: «Професіяаніматор» Ф. Хитрука (Хитрук, 2007), «Сніг на траві» Ю. Норштейна (Норштейн, 2005), у яких основна увага приділяється розумінню творчої суті професії аніматора, розробці питання, пов'язаного з рухом в анімації, та аналізується його роль у побудові анімованих титрів у кінофільмах. До проблеми дослідження саме кінотитрів звернувся Ю. Цив'ян (1988) у роботі «До семіо- 
тики написів у німому кіно: Напис та усна мова» (Цивьян, 1988). Автор зауважує, що з кінця 90-х рр. розпочалась велика семіотична перебудова всієї системи кіномови.

З початком Т. зв. цифрової доби в кінематографічній палітрі з'явились анімовані титри. До ґрунтовного аналізу явища кінотитрів, до історії їх появи треба зачислити дослідження Н. Ізволова «Феномен кіно», в якому автор розглядає кіно у контексті не тільки загально-ідеологічної та естетичних категорій, а й як появу нового феноменального явища, яке народилось на перехресті технологічних, соціальних, економічних та культурних сил (Изволов, 2005). Автори теоретичних досліджень анімованих титрів А. Орлов (1993) та Н. Кривуля (2009) наголошують, що створення титрів сьогодні значною мірою сприймається поверхнево, як ремесло, як технічне мистецтво. Виключно практичний підхід до анімації не здатний відобразити всієї глибини даної сфери діяльності: в анімаційному творі містяться численні художні образи, пласти смислів.

Також для нашого дослідження особливе значення мали роботи В. Позніна: «Аудіовізуальний продукт: технологія плюс творчість» (Познин, 2006), «Виразні засоби екранних мистецтв: естетичний і технологічний аспекти» (Познин, 2009). У цих роботах особлива увага приділяється естетичним та психологічним аспектам сприйняття аудіовізуальної інформації, організації екранного простору і часу, впливу сучасних технологій на формування нової аудіовізуальної естетики. На розробку питань, які стосуються сучасних комп'ютерних технологій і нових медіа, спрямовані праці К. Разлогова «Нові аудіовізуальні технології» і «Мистецтво екрану: від кінематографа до Інтернету» (Разлогов, 1982; Разлогов, 2006).

Дослідження Л. Сухорукової (2017) «Візуальна організація екранного середовища в мультимедійному дизайні» присвячена мультимедійному дизайну, який поєднує у собі комбінацію графіки, тексту, звуку, анімації та відео. Н. Дядюх-Богатько, Я. Куць (2013) у статті «Шрифт в мультимедіа - перспективи розвитку» досліджують виразність шрифта у мультимедійному просторі та його візуальне сприйняття в електронній типографіці.

Автор Ю. Мирошниченко (2014) в статті «Типографіка електронних видань: скерування естетичних орієнтирів» відстежує шлях еволюції типографіки в електронних виданнях від механічної конвертації рис, притаманних традиційному друкованому виданню, до засвоєння візуальної мови сучасного цифрового середовища. М. Мурашко (2015) присвячує роботу «Шрифт як виразний засіб передачі інформації у відео-рекламі» розгляду використання шрифту і типографіки у відео-рекламі та використанню дизайнерами засад зручності читання в рекламних анімаційних фільмах.

Найближче торкнувся теми шрифтової анімації М. Моженко (2018) в роботі «Титри та анімована графіка в кіно та на телеба- 
ченні», де розглянув шрифти в контексті використання та трансформації їх на різноманітному просторі аудіовізуальної продукції.

Підсумовуючи викладене, наголосимо, що лише невелика частка наявних праць торкається проблематики створення анімованих титрів та їх взаємодії з візуальним рядом кінострічок.

\section{Результати дослідження}

Титри є офіційною частиною кінематографічних творів, як обкладинка у книги з позначенням автора, редакторів і видавництва.

Анімовані титри - вид художньої творчості, що відноситься до категорії аудіовізуальних мистецтв, відмінною рисою якої стає «пожвавлення», наділення «душею» образу, штучно створеного за допомогою різноманітних технік і засобів художньої виразності. Анімація стала випробувальним полігоном фантазії, уяви, потоків свідомості: все, що не втілюються в реальному житті, з успіхом реалізуються в анімованій віртуальній реальності, що дозволяє «розіграти» той чи інший сюжет (Артюх, 2010).

Сергій Ейзенштейн називав одним із найважливіших завдань анімації пробудження в людині їі пралогічного мислення, еволюційного, комплексного і чуттєвого погляду на світ і на процеси, що в ньому протікають. Майстра захоплювала жива лінія, яка за допомогою автора малюнку залучає глядача до участі у зміненні світу за його бажанням і фантазією (Эйзенштейн, 1964-1971).

Оскільки до початку 1990-х рр. анімація знаходилась між мистецтвом кінематографу та суто технічним процесом, то належної наукової уваги до вивчення питань анімаційної художньої образності в цей період приділялося значно менше, ніж у кінематографі. Основна увага була спрямована на базові параметри створення анімованих творів: розкриття психофізіологічного аспекту глядацького сприйняття, ідейно-творчих параметрів, виробничих етапів тощо, хоча на кожній студії були художники саме для створення титрів.

Багато мультиплікаторів випробовували різні розважальні прийоми на титрах, щоб не просто донести до глядача важливу інформацію, але ще й захопити його. Так, використовуються різні шрифти, зазвичай або набірні або мальовані «від руки», які навіть анімуються, тобто букви починають рухатися або приймати антропоморфний вигляд і т. д. Пізніше подібні ефекти стали застосовуватися і в кіно. Причому це робилося не тільки в початкових титрах, але й у завершальних.

Сучасний анімаційний твір є симбіозом усіх можливих видів мистецтва і технологічних нововведень. Це концентрація художніх образів і досягнень науки, що оперує на рівні архетипів, симулякрів, символів і колективного несвідомого. Поєднання цих складових дозволяє транслювати у підсвідомість глядача різноманітні ідеї, впливаючи на його психіку з високим ступенем ефективності. 
Незважаючи на те, що багато хто не надає великого значення цьому елементу кінопродукту, більшість режисерів і знімальних студій намагаються зробити креативні та цікаві варіанти. Це дозволяє максимально продуктивно використовувати ресурси хронометражу кінострічки. Титри відіграють все більшу роль при створенні фільму. Їх створенням та реалізацією займаються не тільки окремі фахівці, а іноді й цілі команди.

Розвиток анімованих технік і технологій, так само як і розвиток їі виразних засобів, нерозривно пов'язаний з процесом становлення кінематографа, який справив на анімацію істотний вплив. Анімація переймала і перетворювала появу різних художніх засобів на кожному з етапів становлення, титри не залишились поза полем впливу. Шрифти та типографічні прийоми завжди відтворювали сучасні графічні тенденції. Більше того, даний процес між типографікою та мовою анімації триває у даний час. Починаючи перегляд кінострічки із суто інформаційних текстових блоків (компанія виробник, продюсери, режисери, акторський склад та ін.), ми одразу можемо визначити час їі створення, бо кожному проміжку часу належить певна група шрифтів, варіанти їх компонування, колір, фактури тощо.

Звичайно ж, такі нюанси як шрифтові групи, або варіанти їх накреслення для пересічного глядача не дуже знайомі, але «занурення» у певний проміжок часу, який відбувається на екрані, починається вже з перших секунд перегляду. Тобто за титрами можна простежити зв'язок між загальними сучасними модними тенденціями та розвитком екранного мистецтва. Комп'ютерна анімація не витіснила класичну анімацію. Вона стала черговим етапом в еволюції анімованих технологій, що дозволила вдосконалити анімаційний процес, прискорити і здешевити його. Проектувальники відкрили нові способи перевтілення класичних анімованих зображень у нові способи впливу на глядача.

Відомий теоретик кіно І. Вайсфельд (1981) відзначав, що мистецтво анімаційних титрів містить набагато більше граней, ніж кінематограф. Він підкреслював важливість алегоричних і символічних конструкцій, абстрактного та асоціативного мислення, які допомагають глядачеві пізнавати фізичну реальність із несподіваних для нього ракурсів.

Новаторські анімаційні технології не мають бути самоціллю в кіноіндустрії самі для себе. Надалі розвиток образної виразності художніх прийомів стає допоміжним засобом для створення захопливого емоційного видовища та яскравого художнього ефекту. В свою чергу ці візуальні прийоми впливають на глядацьку свідомість саме завдяки своїй новизні та незвичності.

Анімація набула популярності завдяки своїй особливій мові, яка внаслідок високого ступеня умовності виявляється привабливою для глядача, задовольняючи його потребу у ментальній діяльності через уяву і асоціативне мислення. Аналізуючи 
велику кількість прикладів початкових та фінальних титрів до кінострічок, ми виокремили декілька розповсюджених схем-прийомів, за якими вибудовується типографічний та візуальний ряд, з якого починається перегляд кінострічки.

Перший і найпоширеніший прийом - це використання стандартних шрифтів з простою анімацією. Прості, ненав'язливі шрифти, які можуть рухатися, відштовхуватися один від одного, з'являтися у різних місцях екранного простору, зустрічаються у кінострічках різного жанру - від ліричних картин до екшен-блокбастерів на кшталт «Місія нездійсненна» (всі частини). У кожному продовженні відеоряд змінюється, а шрифт лишається майже незмінним. У кінофільмі «Сніговик», 2017 (Норвегія), виважена і спокійна поява титрів на звичайних засніжених Європейських пейзажах натякає на те, що щось має статися. А лаконічна графіка титрів до кінострічки «Безсмертний Манхетен», 2016, ілюструє можливість «делікатного та ненав'язливого» поєднання графічного зображення на аркуші паперу зі звичайним типографським шрифтом. На деяких зображеннях навіть незрозуміло, де графічна складова, а де починаються титри (рис. 4.1).

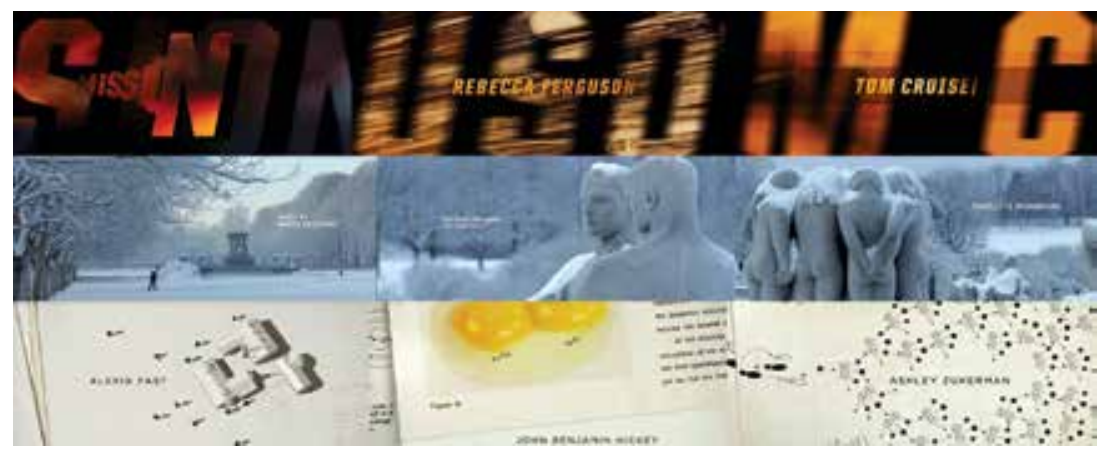

Рис. 4. 1. «Місія нездійсненна 2», 2000. «Сніговик», 2017. «Безсмертний Манхетен», 2016.

Fig. 4.1. «Mission: Impossible I/», 2000. «The Snowman», 2017. «Manhattan Undying», 2016.

Другий, не менш поширений та популярний прийом, шрифтова акциденція, яка викликає певні асоціації, і з першою появою на екрані вже занурює глядача у ще не розпочатий ігровий сюжет. Це можуть бути шрифти, що наслідують певні ознаки минулого часу, наприклад: «Шерлок Холмс», 2009; «Центуріон», 2010; або «нервові, пошкоджені» шрифтові гарнітури з гліч-ефектом, як у кінофільмі «Сім», 1995, чи то шрифти, запозичені з технічних приладів, як у культовій стрічці «Матриця», 1999 р. (рис. 4.2).

Наступний прийом - поєднання шрифтів з роботою камери: обертання, панорама, віддалення або приближення об’єктів тощо. Такий прийом ми бачимо у фільмі Девіда Фінчера «Кімна- 
Деміург: ідеї, технології, перспективи дизайну 2019 Том 2 № 1 Demiurge: ideas, technologies, perspectives of design 2019 Vol. 2 No 1

та страху», 2002: глядач споглядає панорамні види Нью-Йорка, і гігантські об'ємні титри висять уздовж будинків, над парками, поперек вулиць, поблискуючи на сонці, є частиною екстер'єру, тим самим створюючи тривожне відчуття тиску та обмеження простору. Титри до стрічки «Хранителі», 2009, нагадують ожилі старі фотокартки, в яких текстова складова також «працює» разом зі знаковими зображеннями. У фільмі-катастрофі Роланда Еммеріха «Післязавтра», 2004, титри «летять» над поверхнею моря, відкидаючи тіні на крижини, що пропливають, і просвічуючись на сонці (рис. 4.3).

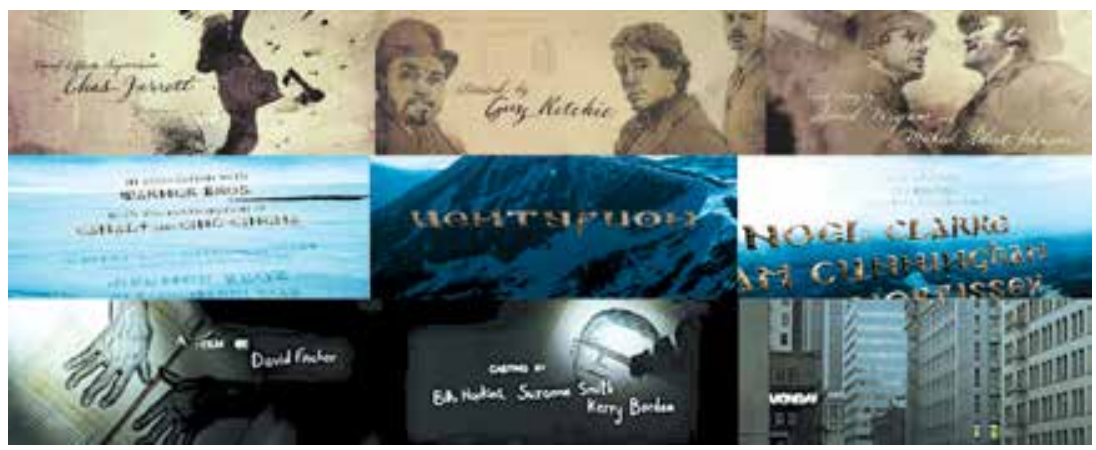

Рис. 4.2. «Шерлок Холмс», 2009. «Центуріон», 2010. «Сім», 1995.

Fig. 4.2. «Sherlock Holmes», 2009. «Centurion», 2010. «Seven», 1995.

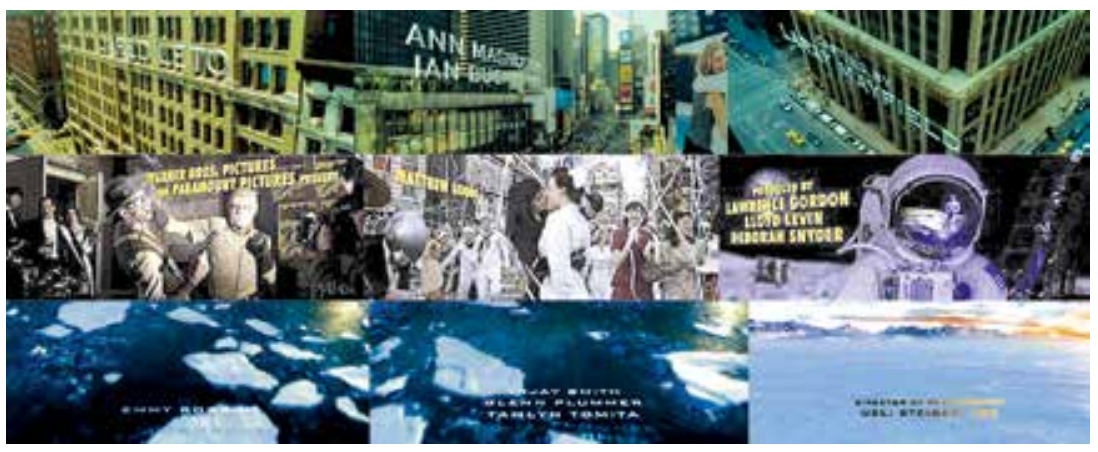

Рис. 4.3. «Кімната страху», 2002. «Хранителі», 2009. «Післязавтра», 2004.

Fig. 4.3. «Panic Room», 2002. «Watchmen», 2009 "The Day After Tomorrow», 2004.

Звичайно ж такий прийом виник і дуже яскраво презентований у кіноепосі «Зоряні війни» ще у 1977 році і створювався він далеко не цифровими технологіями. Сьогодні текст, що рухається у безмежний простір, уже без пояснень «відправляє» глядача у космічне майбутнє, тобто асоціативний ряд починає «працювати» з уже підготовленою свідомістю глядача. 
«Вклеювання» титрів у об'єкти, що супроводжують сюжет,прийом, дотичний до попереднього. Так, у фільмі «Робін Гуд: початок», 2018, титри є невід'ємною складовою зображень а-ля комікс. У кінострічці «Лего», 2014, усі вихідні титри задіяні в анімації будівництва об'єкту з конструктора «Лего» як будівельні елементи. У «Школі року», 2003, титри нанесені на куртки відвідувачів, на плакати в барі, на таблички на дверях, а сама назва - це неонова реклама (рис. 4.4).

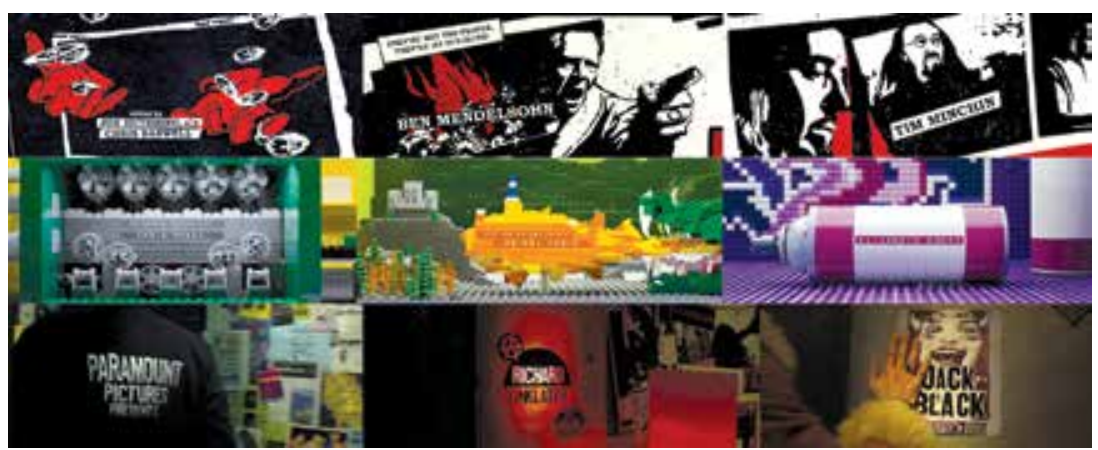

Рис. 4.4. «Робін Гуд: початок», 2018. «Лего», 2014. «Школа року», 2003.

Fig. 4.4. «Robin Hood», 2018. «Lego», 2014. «School of Rock», 2003.

Важливу роль завжди відіграє тло, на якому експонуються титри - статичне або тло «на тлі дії». 3 локальним тлом усе ясно: це завжди просто і благородно. Безумовно, титри «на тлі дії», тобто коли на екрані вже щось відбувається і поверх зображення йдуть титри, - такий прийом є найрозповсюдженішим. Ефектність цього прийому підсилює звуковий супровід, який допомагає розставити акценти в найрізноманітніших варіантах. Наприклад, так звана «історія кулі», яку випустили з пістолета, - початок кінострічки «Збройовий барон», 2005, - чудова ілюстрація цього прийому. У французькій стрічці «Лихоманка», 2016, майже прозорі титри, зникаючи, підсилюють психологічні проблеми головної героїні кінофільму. Разом з кінострічкою «Дедпул», 2016, та головним героєм мутантом Дедпулом, титри до цього фільму визнані одними з найкращих за 2016 рік. У них вдало поєднані візуальний ряд, що виконаний у найкращих традиціях жанру комікс та екшен, зі звичайним шрифтовим гротеском, що зникає за об'єктами, які переміщуються у просторі (рис. 4.5).

Окремий вид та напрямок розвитку - титри-мультфільми. Це особливий жанр. У цьому випадку дія фільму розпочинається чи закінчується міні-мультфільмом, гротескні титри в ньому, зазвичай, роблять запаморочливі трюки, перетворення і т. д. Це вкрай авторські художні рішення, які вже на початку стрічки захоплюють глядача, створивши інтригу, і залучають до дії кінострічки. Стрічка та початок фільму «Біжи, Лоло, біжи» у 1998 р. стали 
Деміург: ідеї, технології, перспективи дизайну 2019 Том 2 № 1 Demiurge: ideas, technologies, perspectives of design 2019 Vol. 2 No 1

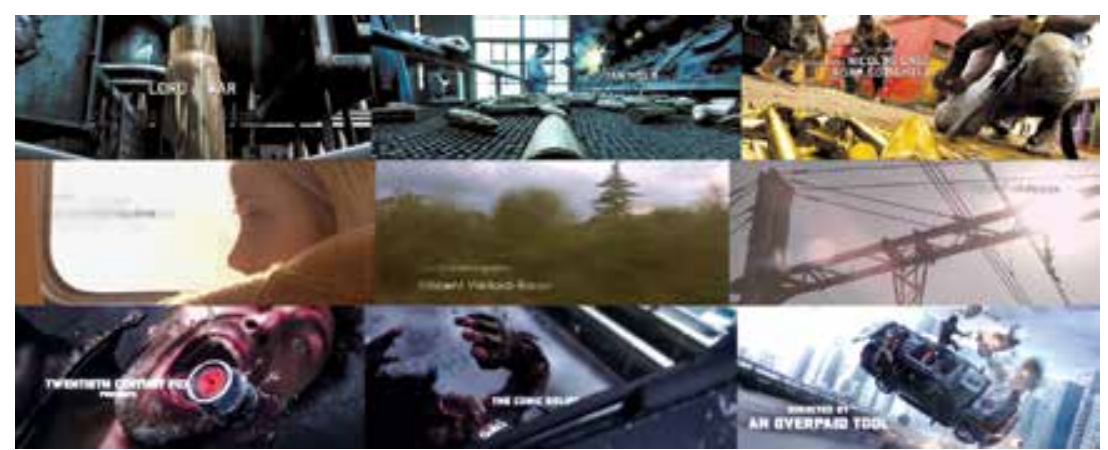

Рис. 4.5. «Збройовий барон», 2005. «Лихоманка», 2016. «Дедпул», 2016.

Fig. 4.5. «Lord of War», 2005. «Fever», 2016. «Deadpool», 2016.

проривом німецького кінематографу. В мультиплікаційному колажі стисло передано суть назви стрічки. Титри до кінофільму «Спіймай мене, якщо зможеш», 2002 р., стали зразком для наслідування. Титри до кінострічки «Джуно», 2007, зроблені настільки оригінально та вишукано, що майже виходять за рамки поняття «титри-мультфільми», тому що створені шляхом покадрового окреслення натурного фільму з реальними акторами, пленером та інтер'єром (рис. 4.6).

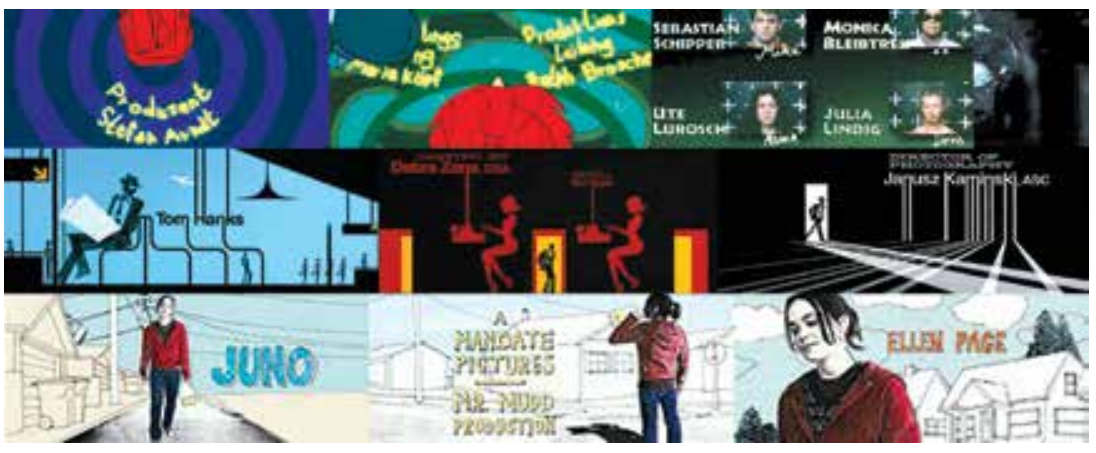

Рис. 4.6. «Біжи, Лоло, біжи», 1998. «Спіймай мене, якщо зможеш», 2002. «Джуно», 2007.

Fig. 4.6. «Run Lola Run», 1998. «Catch Me If You Can», 2002. «Juno», 2007.

Звичайно ж, на цьому перелік засобів створення дизайну титрів до кінострічок не завершується, його можна значно розширити. Створення нових комп'ютерних спецефектів зумовлюють появу таких цікавих початків фільмів, як «Дівчина з татуюванням дракона», 2011, - «рідкий монохром»; «Справжній детектив», 2014, - подвійна експозиція; «Glow», 2017, - ротоскоп з неоновим ефектом; (рис. 4.7) та найвигадливіші сюжети початкових титрів до кінофільмів усієї «бондіани».

Взагалі, за фільмами про агента 007 можна відстежити еволюцію сюжетів початкових титрів протягом 50 років, а саме модні графічні тенденції та вплив розвитку технологій, задіяних 


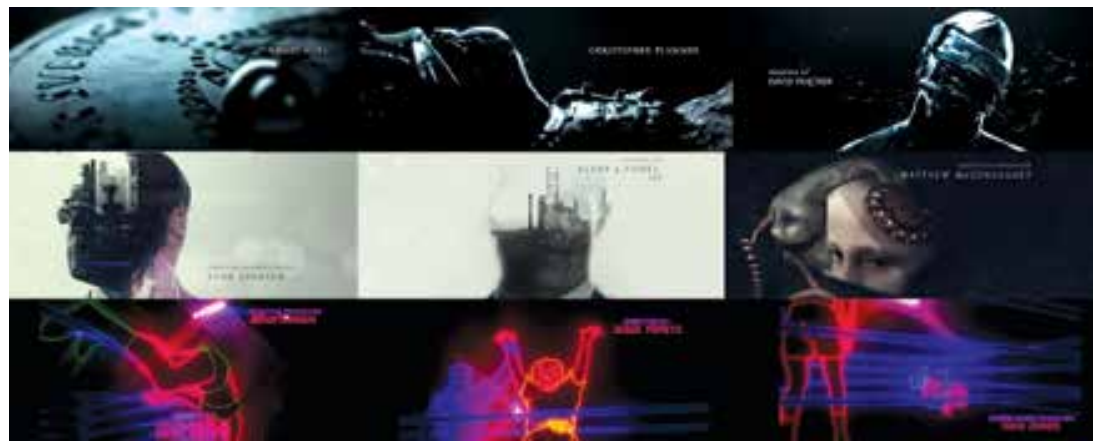

Рис. 4.7. «Дівчина з татуюванням дракона», 2011. «Справжній детектив», 2014. «Блиск», 2017.

Fig. 4.7. «The Girl with the Dragon Tattoo», 2011. «True Detective», 2014. «GLOW», 2017.

у кіноіндустрії. Спочатку це була або класична анімація, або комбіновані зйомки в поєднанні з модними шрифтами. А вже останні серії $€$ зразковим прикладом комп'ютерної анімації, хоча використання шрифту залишається достатньо класичним та «стриманим» (рис. 4.8).

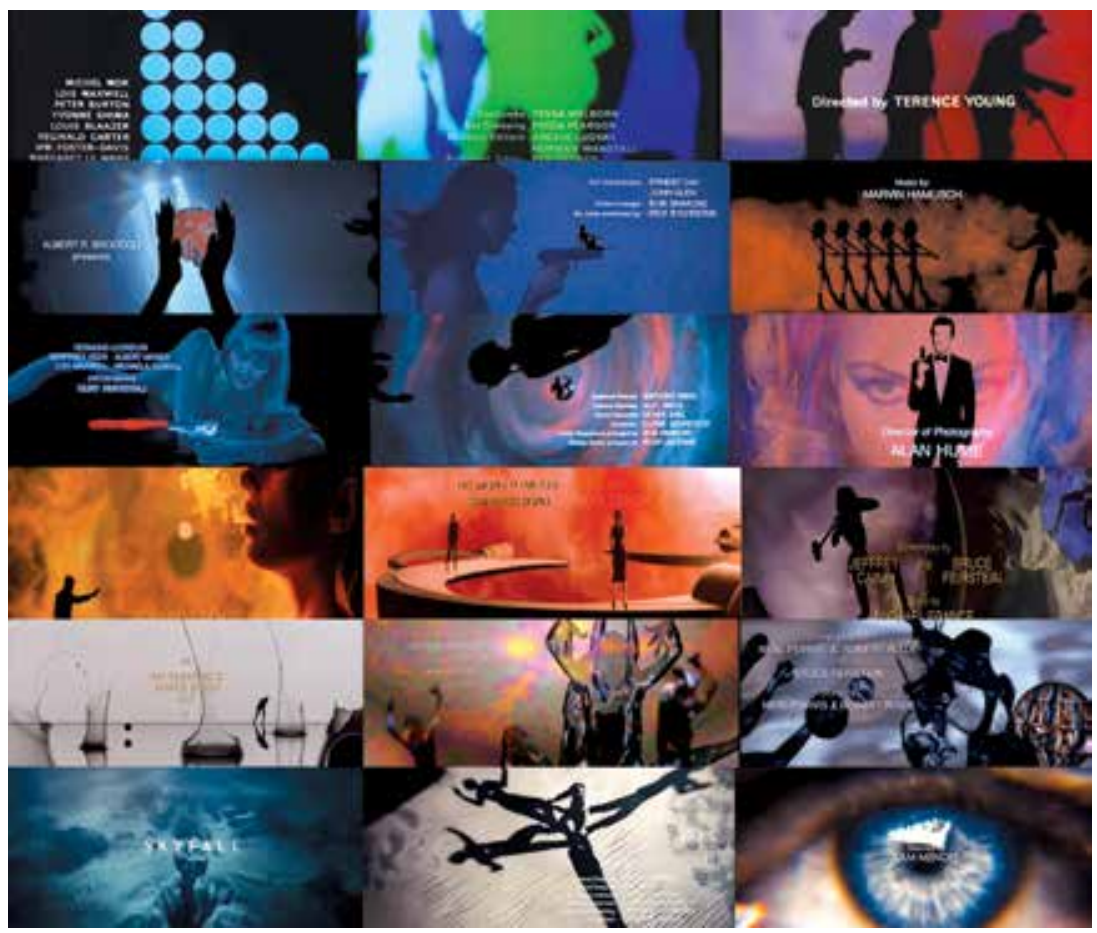

Рис. 4.8. «Доктор Ноу», 1962. «Шпигун, який мене кохав», 1977. «Восьминіжка», 1983. «Золоте око», 1995. «l цілого світу замало», 1999. «007: Координати «Скайфолл»», 2012.

Fig. 4.8. «Dr. No», 1962. «The Spy Who Loved Me», 1977. «Octopussy», 1983. «Golden Eye», 1995. «The World Is Not Enough», 1999. «Skyfall», 2012. 
Титри до кіноепопеї «Горець» також зазнали істотних змін. У першому фільмі 1986 року солідні червоні титри строго центровані на чорному екрані. Музики групи «Queen» цілком вистачає для створення героїчної атмосфери. Титри до кожної з наступних частин радикально відрізняються від попередніх. Через 14 років у четвертому фільмі «Горець: Кінець гри» титри хаотично з'являються в різних кутах темного екрану з грозовими хмарами і далекими блискавками, на тлі ледь помітної розмітки, на якій виникають та зникають окремі рядки з прізвищами, які ще й рухаються у протилежні боки один від одного (рис. 4.9).

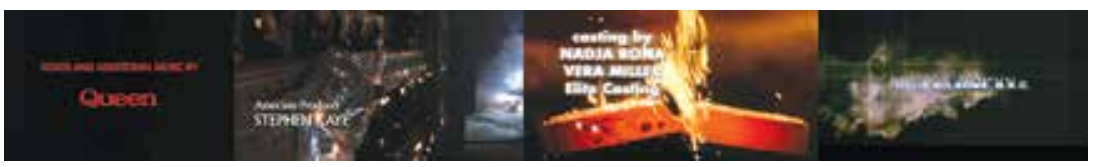

Рис. 4.9. «Горець», 1986. «Горець 2: Пожвавлення», 1991.

«Горець: Останній вимір», 1994. «Горець: Кінець гри», 2000.

Fig. 4.9. «Highlander», 1986. «Highlander II: The Quickening», 1991.

«Highlander: The Final Dimension», 1994. «Highlander: Endgame», 2000.

Крім професійного рівня володіння навичками використання графічних та анімаційних засобів, знань сучасних технологій, у кожному новому проекті до творчого або технічного завдання дизайнера часто входить освоєння досить великого обсягу нової інформації для відповідності до сценарного плану і сюжету. Чим складніший проект, тим більше він наповнений різноманітною інформацією. Дизайнеру доводиться удосконалювати методи проектування, в тому числі шукати найзручніші, чіткі, швидко зчитувані способи шрифтової графічної фіксації для взаємодії візуальних і звукових (шумових або музичних) тематичних ліній, узгодження всіх елементів мультимедійної композиції.

Сучасні технології розширили та збагатили робочий інструментарій, технологічні вдосконалення економлять час і зусилля, розширюють можливості проектувальників. Шрифтова анімація сприймається ще активніше, аніж красиві статичні тексти. Проте всі етапи роботи при створенні шрифтового анімованого звернення є синергетичним продуктом, що поєднує дослідницьку роботу, теоретичні знання різних напрямків дизайнерської діяльності та практичний досвід.

\section{Наукова новизна та практична значимість дослідження

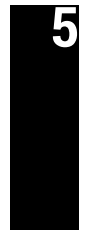

Полягає в уточненні основних напрямків створення анімованих титрів на основі виокремлених зразків художніх фільмів цифрової доби. Аналізуючи приклади, нами було виявлено декілька беззаперечних підходів, які вдало поєднують у собі поставлені авторами / сценаристами кінострічок завдання: шрифтові рішення на базі стандартних шрифтів; шрифтова акциденція, яка має викликати певні асоціації; поєднання шрифтів з роботою камери (обертання, панорама, віддалення або приближення об'єктів тощо); «вклеювання» титрів в об'єкти; тло, на 
якому експонуються титри - статичне або тло «на тлі дії»; та титри-мультфільми як особливий жанр та окремий напрямок розвитку в анімації титрів.

Висновки 6 Діяльність дизайнера у розробці анімованих титрів для кінострічок вимагає певних теоретичних орієнтирів, хоча абсолютних правил для вибору і поєднання різних видів шрифтових гарнітур та зображень не існує. У результаті аналізу значного об’єму візуальної інформації маємо підсумувати, що на сучасному етапі саме поєднання візуального ряду та простих шрифтових гарнітур є запорукою вдалих проектних рішень. Наведеними у дослідженні прийомами використання та поєднання шрифтів з візуальним рядом лише окреслено можливості для наступного дослідження. Надалі розвиток технологічних процесів, задіяних у практичній роботі, майже «зітре» межі між згаданими угрупованнями. Таке «зіткнення» шрифтів з різними видами зображень та технічними новаціями вимагатиме від роботи над проектом поєднання дослідницького процесу, базових теоретичних знань і практичного досвіду. Отриманий синергетичний кінцевий продукт має викликати у глядача певні запрограмовані виробниками емоції та налаштовувати глядачів на подальший і можливо неодноразовий перегляд кінострічки.

\section{Список бібліографічних посилань}

Артюх, А.А. (2010). Смена парадигмы развития киноискусства и киноиндустрии США: от классического Голливуда к новому Голливуду. (Диссертация доктора искусствоведения). Санкт-Петербургский государственный университет кино и телевидения, Санкт-Петербург.

Вайсфельд, И.В. (1981). Искусство в движении: Современный процесс. Исследования, размышления. Москва: Искусство.

Дядюх-Богатько, Н.Й., \& Куць, Я.Й. (2013). Шрифт в мультимедіа - перспективи розвитку. Вісник Харківської державної академії дизайну і мистецтв, 1, 30-31.

Изволов, Н. (2005). Феномен кино: история и теория. Москва: Материк.

История фильмов про Джеймса Бонда («бондиана»). (2012). Взято из https://ria. ru/20121005/764571540.html.

Кривуля, Н.Г. (2009). Эволюция художественных моделей в процессе развития мировых аниматографий. (Диссертация доктора искусствоведения). Всероссийский государственный институт кинематографии, Москва.

Марченко, М.Н., \& Яроменко, А.В. (2015). Обоснование термина «Мультимедийный дизайн» В контексте моушендизайна. Международный журнал экспериментального образования, 12-2, 241-242. Взято из http://www.expeducation.ru/ru/article/ view?id=9064.

Мирошниченко, Ю.С. (2014). Типографіка електронних видань: скерування естетичних орієнтирів. Вісник Харківської державної академії дизайну і мистецтв, 2, 25-28.

Моженко, М.В. (2018). Титри та анімована графіка в кіно та на телебаченні. Мистецтвознавчі записки, 33, 330-337.

Мурашко, М.В. (2015). Шрифт як виразний засіб передачі інформації у відео-рекламі. Вісник Харківської державної академії дизайну і мистецтв, 5, 26-35. 
Норштейн, Ю. (2005). Снег на траве. Фрагменты книги. Лекции по искусству анимации. Москва: Всероссийский государственный институт кинематографии.

Орлов, А.М. (1993). Духи компьютерной анимации. Москва: МИРТ.

Познин, В.Ф. (2006). Аудиовизуальный продукт: технология плюс творчество. СанктПетербург: Санкт-Петербургский государственный университет кино и телевидения.

Познин, В.Ф. (2009). Выразительные средства экранных искусств: эстетический и технологический аспекты. (Диссертация доктора искусствоведения). Санкт-

Петербургский Гуманитарный университет профсоюзов, Санкт-Петербург.

Разлогов, К.Э. (1982). Искусство экрана: проблемы выразительности. Москва: Искусство.

Разлогов, К.Э. (2010). Искусство экрана: от синематографа до Интернета. Москва: РОССПЭН. Сухорукова, Л.А. (2017). Визуальная организация экранной среды в мультимедийном дизайне. Вісник Харківської державної академії дизайну і мистецтв, 2, 32-34.

Хитрук, Ф. (2007). Профессия - аниматор. Москва: Гаятри.

Цивьян, Ю.Г. (1988). К семиотике надписей в немом кино (надпись и устная речь). В Зеркало. Семиотика зеркальности. Труды по знаковым системам 22. (Выпуск 831, с. 143-154).

Тарту: Издательство Тартуского университета.

Эйзенштейн, С.М. (1964-1971). Избранные произведения. (Т. 5). Москва: Искусство.

\section{References}

Artiukh, A.A. (2010). Smena paradigmy razvitiia kinoiskusstva i kinoindustrii SShA: ot klassicheskogo Gollivuda knovomu Gollivudu [Change the paradigm of cinema and film industry development in the USA: from classical Hollywood to a new Hollywood]. (Doctor's thesis). St. Petersburg State University of Film and Television [in Russian].

Diadiukh-Bohatko, N.Y., \& Kuts, Ya.Y. (2013). Shryft v multymedia - perspektyvy rozvytku [Font in multimedia - development perspectives]. Visnyk Kharkivskoi derzhavnoi akademii dyzainu i mystetstv, 1, 30-31 [in Ukrainian].

Eizenshtein, S.M. (1964-1971). Izbrannye proizvedeniia [Selected Works]. (Vol. 5). Moscow: Iskusstvo [in Russian].

Istoriia filmov pro Dzheimsa Bonda („bondiana”) [The history of films about James Bond („Bond”)]. (2012). Retrieved from https://ria.ru/20121005/764571540.html [in Russian].

Izvolov, N. (2005). Fenomen kino: istoriia i teoriia [The phenomenon of cinema: history and theory]. Moscow: Materik [in Russian].

Khitruk, F. (2007). Professiia - animator [Profession - animator]. Moscow: Gaiatri [in Russian].

Krivulia, N.G. (2009). Evoliutciia khudozhestvennykh modelei $v$ protcesse razvitiia mirovykh animatografii [The evolution of artistic models in the development of world animatographies]. (Doctor's thesis). All-Russian state institute of cinematography, Moscow [in Russian].

Marchenko, M.N., \& laromenko, A.V. (2015). Obosnovanie termina "Multimediinyi dizain" v kontekste moushendizaina [Justification of the term "Multimedia Design" in the context of motion design]. Mezhdunarodnyi zhurnal eksperimentalnogo obrazovaniia, 12-2, 241-242. Retrieved from http://www.expeducation.ru/ru/article/view?id=9064 [in Russian].

Mozhenko, M.V. (2018). Tytry ta animovana hrafika v kino ta na telebachenni [Titles and animated graphics in cinema and on television]. Mystetstvoznavchi zapysky, 33, 330-337 [in Ukrainian].

Murashko, M.V. (2015). Shryft yak vyraznyi zasib peredachi informatsii u video-reklami [Font as an express means of transmitting information in video advertising]. Visnyk Kharkivskoi derzhavnoi akademii dyzainu i mystetstv, 5, 26-35 [in Ukrainian].

Myroshnychenko, Yu.S. (2014). Typohrafika elektronnykh vydan: skeruvannia estetychnykh oriientyriv [Typography of electronic publications: guiding aesthetic landmarks]. Visnyk Kharkivskoi derzhavnoi akademii dyzainu i mystetstv, 2, 25-28 [in Ukrainian].

Norshtein, lu. (2005). Sneg na trave: Fragmenty knigi: Lektcii po iskusstvu animatcii [Snow on the grass: Fragments of the book: Lectures on the art of animation]. Moscow: All-Russian state institute of cinematography [in Russian].

Orlov, A.M. (1993). Dukhi kompiuternoi animatcii [Perfume computer animation]. Moscow: MIRT [in Russian]. 
Poznin, V.F. (2006). Audiovizualnyi produkt: tekhnologiia plius tvorchestvo [Audiovisual product: technology plus creativity]. St. Petersburg: St. Petersburg State University of Film and Television [in Russian].

Poznin, V.F. (2009). Vyrazitelnye sredstva ekrannykh iskusstv: esteticheskii i tekhnologicheskii aspekty [Expressive means of screen arts: aesthetic and technological aspects]. (Doctor's thesis). St. Petersburg University of the Humanities and Social Sciences, St. Petersburg [in Russian].

Razlogov, K.E. (1982). Iskusstvo ekrana: problemy vyrazitelnosti [Screen art: problems of expressiveness]. Moscow: Iskusstvo [in Russian].

Razlogov, K.E. (2010). Iskusstvo ekrana: ot sinematografa do Interneta [Screen art: from cinema to the Internet]. Moscow: ROSSPEN [in Russian].

Sukhorukova, L.A. (2017). Vizualnaia organizatciia ekrannoi sredy v multimediinom dizaine [Visual organization of the screen environment in multimedia design]. Visnyk Kharkivskoi derzhavnoi akademii dyzainu i mystetstv, 2, 32-34 [in Russian].

Tcivian, lu.G. (1988). K semiotike nadpisei v nemom kino (nadpis i ustnaia rech) [To semiotics of inscriptions in silent films (inscription and oral speech)]. In Zerkalo. Semiotika zerkalnosti. Trudy po znakovym sistemam 22 [Mirror. Semiotics mirroring. Works on sign systems 22]. (Issue 831, pp. 143-154). Tartu: Izdatelstvo Tartuskogo universiteta [in Russian].

Vaisfeld, I.V. (1981). Iskusstvo v dvizhenii: Sovremennyi protcess. Issledovaniia, razmyshleniia [Art in motion: The modern process. Research, reflections]. Moscow: Iskusstvo [in Russian]. 